\title{
MELANGKAH KE DALAM DUNIA MISTIKNYA WILIAM JAMES
}

\author{
Andreas Maurenis*
}

\begin{abstract}
Abstrak
Mystical experience has become a new discourse and has been resounded in the midst of our world which has lost the feel of its religiosity due to modernism and secularism. Though modernism gives advance in human life but it is undeniable that somehow it affects to the very core of human thirst for a deepest spiritual growth and improvment. So, in this part William James has become one of the most known philosophers in nineteen century and in the same time as a psychologist who tries to bring back the mystcal experience as a vessel for every individual to find the true meaning of their spirituality need. James is going to re-present this encountered-experience with the transcendent reality into the midst of human being's world day to day. By deepest reflection of knowledge, James tries to understand the mystical experience by giving the comparison of mystical experience with some psychology aspect. In other hand, he favors to let people know how the rasionalism deals with this kind of spiritual encounters. And he explains too, how the mystical experience comes to human's life. Further, James also gives the understanding of mystical experience as far as it useful for the personal growth and the growth of social relationship in human being's life.
\end{abstract}

Kata-kata kunci: mystical experiences, modernism, spritual growth, personal growth, social relationship, rasionalism, psychology aspect.

\section{Introduksi}

Dunia dewasa ini dipenuhi dengan berbagai corak kehidupan yang sarat akan fenomena dan melibatkan banyak pihak. Begitu banyak fenomena tersebar luas, melintas batas dan waktu. Fenomena itu lahir, hidup dan mengalir bersama dengan pengalaman manusia, entah secara kelompok maupun personal. Sekian banyak fenomena yang ada, tidak dipungkiri, melahirkan banyak kekhasan dalam khazanah hidup.

* Andreas Maurenis, Mahasiswa Pasca Sarjana Universitas Katolik Parahyangan Bandung. 
Fenomena itu ada dalam pengalaman hidup manusia. Begitu juga sebaliknya, pengalaman hidup manusia akhirnya menjadi sebuah fenomena yang perlu dimaknai.

Pengalaman hidup manusia selalu beragam dan dinamis namun tidak terus awet, walaupun bervariasi namun tidak menetap dan melekat dalam diri. Pengalaman itu ada dan dirasakan hanya ketika manusia berjuang menemukan eksistensinya di dunia yang serba fenomenal ini. Ibarat bahasa yang beragam demikian pula pengalaman itu sendiri. Satu dari sekian banyak pengalaman yang fenomenal sekaligus menarik perhatian adalah pengalaman hidup manusia dengan realitas transenden.

Pengalaman ini menggambarkan bahwa sejak manusia pertama kali ada dan hidup di dunia ini, ia selalu berelasi dengan dunia transendental. Suatu dunia metafisik yang selalu menjadi perhatian manusia, bahkan pada titik tertentu menjadi pola dasar dan membentuk pribadi manusia menjadi identitas yang unik. Pengalaman keterikatan dengan realitas transenden yang dirasakan manusia dalam berbagai dimensi hidup ini membantu manusia dalam menemukan diri yang sejati. 
William James ${ }^{1}$, melalui karyanya The Varieties of Religious Experience, secara mendalam memperlihatkan ragam pengalaman mistik manusia. James, dengan memperlihatkan ragam pengalaman mistik, berusaha untuk membuat manusia "lahir kembali" ke dunia yang sama. James memberi wawasan baru yang inspiratif kepada setiap individu untuk menghadapi dengan kesadaran segala ketidakpastian zaman dan kemudian memilih tindakan yang tepat untuk pemenuhan kehidupan mereka melalui alternatif yang satu ini (pengalaman mistik). Sebuah alternatif yang sebenarnya sangat tidak asing bagi dunia yaitu pemenuhan kebutuhan batin. Manusia diajak untuk tidak melulu

1 William James lahir di New York City, Amerika Serikat pada tanggal 11 Januari 1842. Ia meninggal di Tamworth, New Hampshire, Amerika Serikat pada tanggal 26 Agustus 1910 pada umur 68 tahun. James adalah filsuf dan psikolog Amerika yang paling berpengaruh, dia dilahirkan di kota New York, akan tetapi menghabiskan masa kecilnya di Eropa. Sebagai seorang filsuf abad ke-19 ia menjadi kolega para filsuf terkenal terutama dalam pencetusan ide-ide pragmatisme seperti Charles Sanders Peirce (1839-1914) dan John Dewey (18591952). Popularitas dan kecerdasannya dipercaya sebagai seorang filsuf yang paling berpengaruh dalam dunia abad ke-19 dan diyakini sebagai filsuf terbaik pada zamanya yang pernah "dilahirkan" oleh dunia Amerika Serikat. Karyakaryanya turut memberi andil pada pemikiran para filsuf lain seperti Émile Durkheim (1858-1917), Du Bois (1868-1963), Edmund Husserl (1859-1938), Bertrand Russell (1872-1970), Ludwig Wittgenstein (1889-1951), Hilary Putnam (1926), and Richard Rorty (1931-2007). James adalah penulis yang produktif dan berbakat di bidang filsafat, psikologi dan pendidikan, dan pengaruhnya pada kehidupan pendidikan di Amerika sangatlah mengesankan. Karya terbesar dan paling berpengaruh The Principles of Psychology (Dasar-dasar Psikologi), yang diterbitkan tahun 1980, kemudian menjadi materi pendidikan. Pemikirannya terhadap pendidikan dan pandangannya terhadap cara kerja pengajar dapat dilihat di karyanya yang terkenal Talks to Teacher. Selain sangat terkenal, bukubuku ini memberikan pengaruh yang besar terhadap pendidikan dan pengajarnya. Teori dan praktek pendidikan, adalah hutang terbesar Amerika kepada "Bapak Pendidikan Psikologi Modern" ini. Selain beberapa tulisan yang sudah disebutkan di atas, terdapat pula beberapa tulisannya yang boleh dikatakan sangat menggugah pemikiran abad ke-20 dan bahkan dunia modern seperti The Will to Believe yang sedikit banyak mengajak manusia untuk menyadari bahwa dalam hidup ada waktu-waktu ketika kita dihadapkan pada situasi yang menuntut seorang harus membuat keputusan tanpa memiliki semua bukti yang mungkin dikuasai. The Varieties of Religious Experiences adalah karya lain dari James yang memuat usaha besarnya untuk menilai arti agama dalam kehidupan manusia. Lihat https:/ /afidburhanuddin.wordpress.com/2012/11/05/william-james-biografidan-pemikiran/ dan https://id.wikipedia.org/wiki/William_James 
berkonsentrasi pada hal-hal luaran namun melangkah ke dalam diri untuk melihat sejauh mana kedua sisi hidupnya, rohani dan jasmani, berkembang dengan selaras. Tawaran James untuk kembali ke dalam pengalaman batin mengisyaratkan bahwa nilai spiritualitas yang diperoleh melalui pengalaman perjumpaan dengan realitas transenden dalam hidup merupakan sisi yang paling signifikan dan paling positif. Prespektif mistik yang dikaji oleh James ingin membantu melahirkan harapan bagi manusia untuk mencapai makna hidup sejati tanpa dibayang-bayangi modernisasi dan sekularisasi yang juga membantu perkembangan manusia namun sekaligus melucuti "pakaian batin" seorang individu.

Tawaran James, setidaknya memberikan insight yang berbuah dan mengakar dalam hidup pribadi-pribadi yang mengalaminya sehingga menjadikan mereka sebagai pribadi-pribadi yang otentik, terinspirasi dan diubah.

\section{Apa Itu Pengalaman Mistik?}

Pemahaman tentang mistik, dari waktu ke waktu, seakan mengalami evolusi. Setiap zaman manusia selalu berusaha memahami mistik sesuai dengan pengalaman hidupnya. Mistik diartikan ulang sesuai dengan kebutuhan manusia dalam zamannya. Bahkan setiap pribadi yang pernah mengalami pengalaman mistik, tak tanggung-tanggung menjabarkan mistik sejauh yang ia pahami dan begitu personal. Berbagai macam definisi tentang mistik dan pengalaman mistik, menciptakan sensasi baru, kaya akan makna sekaligus menjawab kerinduan manusia, yang terlihat bosan dengan multikulturalisme dunia dengan berbagai tawaran yang serba instan.

Mistik sering timbul bila hidup agama menjadi terlalu legalistis dan terlampau melembaga serta kurang mendukung hubungan erat hati orang beriman dengan Tuhannya. ${ }^{2}$

Saat mistik menjadi esensi lain dalam spiritualitas manusia kontemporer, mistik lalu ditempatkan dalam berbagai ranah pemikiran dan dikemas lalu dimasukkan dalam wadah-wadah yang kaya akan makna. Di satu sisi mistik berada dalam wadah yang begitu sekuler atau profan namun di sisi lain berada dalam wadah yang lebih religius.

2 A. Heuken SJ, Ensiklopedia Gereja, Jakarta, Yayasan Cipta Loka Caraka, 2005, Hal. 254 
Mistik seringkali dimengerti untuk memaknai sebuah pengalaman yang berada di luar jangkauan atau ruang lingkup pengalaman inderawi biasa, yaitu pengalaman yang mentransendenkan realitas inderawi dan bahkan citra mental ${ }^{3}$.

Bahkan dalam kebudayaan barat modern, Otto menggambarkan mistisisme sebagai sesuatu yang nonrasional ${ }^{4}$. Sebelum lebih jauh memahami apa itu mistik, perlulah pertama-tama melihat istilah mistik itu sendiri. Mistik berasal dari bahasa Yunani yakni mystikos yang berarti rahasia, serba rahasia, tersembunyi, gelap atau terselubung dalam kekelaman. Lalu arti ini diperluas sebagai sebuah paham yakni paham mistik atau mistisisme yang berarti paham yang memberikan ajaran serba mistis sehingga hanya dikenal atau dipahami oleh orangorang tertentu saja terutama sekali, penganutnya.

Arberry menulis demikian, it has become a plentitude to observe that mysticism is essentially one and the same, whatever the religion professed by the individual mystic: a constant and unvarying phenomenon of the universal yearning of the human spirit for personal communion with God5

Pemahaman lebih jauh dari ungkapan Arberry adalah bahwa mistik akan selalu berkaitan dengan kerinduan pribadi untuk bertemu Allah dalam hidup, sesama dan diri sendiri. Underhill seorang tokoh penting awal studi mistisisme mengartikan mistik sebagai seni bersatu dengan Realitas, kesatuan antara Tuhan dan jiwa manusia ${ }^{6}$. Tillich mengartikan mistisisme sebagai sebuah kategori yang terutama berkenaan dengan pengalaman-pengalaman yang tak terlukiskan, eksatis. ${ }^{7}$ Sementara bagi Freud, mistik adalah seperti musik, sebuah buku yang tertutup. ${ }^{8}$

Bagi James, pemahaman tentang pengalaman mistik diramu dalam kelompok karakter pengalaman mistik yaitu kualitas noetik, situasi transien, kepasifan dan tak terungkapan. Bagi James, kualitas noetik sangat

3 Richard King, Agama, Orientalisme dan Poskolonialisme, Yogyakarta, Qalam, 2001, Hal. 29

${ }^{4}$ Op. Cit, Richard King, Hal. 47 Press, 1961

${ }^{5}$ R.C Zaehner, Mysticism Sacred and Profan, London, Oxford University Hal. 8

6 Evelyn Underhill, Practical Mysticism, USA, Ebook Directory, 1915,

${ }^{7}$ Loc. Cit, Richard King, Hal. 18.

8 William B. Parsons, The Enigma of the Oceanic Feeling, New York, Oxford University Press, 1999 
mirip dengan perasaan atau situasi berpengetahuan yang artinya, wawasan tentang kebenaran tidak bisa digali melalui intelek yang bersifat diskursif, tidak bisa dikatakan dan hanya bisa dirasakan. Situasi transien yaitu situasi yang hanya berlangsung sekitar setengah jam atau paling lama satu jam, kualitasnya bisa diproduksi dalam ingatan meskipun tidak terlalu sempurna. Tetapi jika momen ini kembali maka akan dikenali lebih mudah. Maksud dari kepasifan bagi James adalah situasi direngkuh dan dikuasai oleh kekuatan yang lebih tinggi, sering dikaitan dengan kepribadian sekunder seperti ucapan kenabian, penulisan otomatis atau keadaan kesurupan. Sementara tak terungkapkan mau mengatakan bahwa pengalaman ini tidak bisa diungkapkan, tidak ada uraian manapun yang memadai untuk bisa mengisahkannya dalam kata-kata. Empat karakter di atas kurang lebih memberi pemahaman tentang pengalaman mistis menurut James. Bagi James pengalaman mistik ini lahir dari kualitas pribadi dalam hubungan dengan yang Ilahi. Pengalaman seperti ini, bagi James, lahir dalam bentuk penghayatan individu, bukan secara institusional, karena itu lebih berurusan dengan sikap batin seseorang dalam relasinya dengan yang Ilahi. Dengan pemahaman James tentang pengalaman mistik ini maka secara tidak langsung, bisa diartikan bahwa James berbicara tentang pengalaman mistik dalam wadah yang lebih membiasakan hal-hal yang lebih bersifat religius, yang selalu hadir dalam hidup dan perjuangan individu tertentu karena adanya hubungan personal yang begitu intim. Intimasi dengan ralitas transenden selalu membangkitkan sensitivitas kesadaran sehingga membuat individu-individu tertentu mampu mengenal perasaan-perasaan aneh yang muncul dalam dirinya tanpa terduga. Walaupun James sendiri berpendapat bahwa pengalaman-pengalaman religius selalu berakar dan berpusat pada kondisi keadaan mistis tetapi ia cenderung untuk menyebut dengan pengalaman religius dari pada pengalaman mistis.

\section{Hadirnya Pengalaman Mistik}

Munculnya suatu fenomena dalam hidup manusia selalu berkaitan erat dengan penyebabnya. Suatu hal tidak akan pernah muncul sendiri. Pasti ada hal lain yang menjadi faktor penyebabnya. Apapun situasi dan kondisi yang dialami manusia ada latar belakangnya tersendiri. Begitu juga dengan spiritualitas manusia. Manusia dan spiritualitasnya tidak dapat dilepaspisahkan dari apa yang kita sebut sebagai pengalaman. Memang benar hidup manusia dikelilingi dengan berbagai pengalaman. Dan yang mau ditekankan dalam pembahasan ini adalah pengalaman manusia dengan realitas lain yang diyakini punya pengaruh luar biasa 
dalam hidupnya. Berkaitan dengan penyebab, maka tidak dipungkiri kalau pengalaman mistik yang seringkali terjadi dalam hidup seseorang, pasti tidak luput dari faktor penyebabnya. Artinya ada suatu telaah lebih lanjut untuk melihat hal-hal apa saja yang menyebabkan manusia berjumpa dengan pengalaman bersentuhan dengan realitas lain. Atau hanya sekedar mimpi atau akibat khayalan manusia belaka. Banyak pendapat yang berusaha menegaskan alasan dibalik suatu pengalaman yang bersifat mistik religius. Pengalaman seperti ini bisa saja terjadi karena kondisi psikofisiologis dan kesehatan seseorang. James sejak awal tidak menyetujui pandangan-pandangan para pakar yang menganggap fenomena keagamaan dan pengalaman rohani manusia selalu berkaitan dengan atau bahkan berawal dari kondisi psikofisiologi dan kesehatan seseorang. Maksud dari kondisi ini adalah orang yang memiliki gangguan mental. James mengatakan bahwa antara kondisi psikofisik dengan keluhuran karakter benar-benar berbeda dimensinya. Artinya kondisi hidup yang sarat dengan kualitas dan nilai-nilai luhur termasuk dimensi spiritual. Maka penilaian yang satu tidak boleh ditarik dari dan untuk hal lain. Dengan kata lain, penilaian atas karya agung seorang tokoh tidak boleh berpijak pada asal-usul atau kondisi psikofisik, yang mungkin saja diderita.

Selain pemahaman-pemahaman yang berbeda antara James dengan para filsuf lain tentang perjumpaan manusia dengan pengalaman akan realitas transenden, terdapat pula alasan situasi dan kondisi lain. Perlu diingat bahwa manusia secara sehat mengakui adanya realitas lain. Sikap keterbukaan ini sudah dengan sendirinya memberi kualitas baru dalam diri setiap individu yang hidup. Maka hal keterbukaan ini selalu merujuk pada sikap manusia membuka dirinya pada penyingkapan realitas transenden tersebut. Keterbukaan atas keyakinan yang penuh kesadaran ini membawa manusia pada konklusi, tidak hanya mengakui realitas transenden tetapi bahkan menghormatinya dengan berbagai macam symbols of worship. Hal ini pun (worship) dilakukan manusia karena adanya dampak positif yang dialami sebagai hasil dari kontekstualisasi keyakinannya itu. Secara praktisnya dapat kita lihat dalam ritual agama rakyat dan devosi dalam lingkup keberagamaan. Simbol-simbol dan semua bentuk pengakuan manusia akan hadirnya realitas transenden kemudian menjadi satu inpirasi hidup yang tidak akan pernah dilupakan begitu saja.

Mistisisme ala Yunani adalah dewa dewi sebagai realitas gaib pengatur hidup. Itulah inspirasi mereka. Itulah tuhan-nya mereka pada waktu itu. Bisa saja berbeda dengan keyakinan manusia di zaman ini atau dengan 
masyarakat di belahan benua lain. Namun tidak bisa diberi cap totally wrong. Setiap zaman, setiap individu, setiap suku bangsa, atau kelompok punya keyakinan sendiri, pengalaman yang berbeda dan penamaan masing-masing. Selain kesadaran akan hadirnya realitas asing yang akhirnya memberi warna tersendiri dalam perjalanan hidup manusia, pengalaman ini juga memberi suatu rekonsiliasi pada hidup manusia. Dengan kata lain, ada kerinduan manusia untuk berjumpa dengan Tuhannya. Berangsur-angsur manusia semakin berusaha untuk membuka dirinya pada Ada. Mungkin berawal pada kejatuhan manusia lalu ada sebuah metanoia hidup.

\section{Pengalaman Mistik Dan Rasionalisme}

Superioritas rasionalisme akan selalu berusaha untuk membatasi segala bentuk keyakinan batiniah seseorang. Apapun intuisi yang dialami seseorang pasti dipertanyakan, bila perlu harus ada alasan yang masuk akal agar bisa diterima. Tidak butuh banyak abstraksi, apalagi hanya mengandalkan perasaan atau kesadaran. Inilah bagi James, dikatakan sebagai momok dalam penggagasan diskursus tentang pengalaman mistik. Rasionalisme menjadi hakim atas realitas mistik. Apapun yang ada dalam keyakinan, atau dalam pengalaman batin seseorang pasti diragukan oleh yang namanya rasionalisme. Mengapa? Alasannya, rasionalisme tidak butuh suatu yang hanya sekedar menduga lalu dimunculkan ke publik untuk dikenang. Rasionalisme butuh sesuatu yang jelas, masuk akal dan dimengerti. Butuh fakta-fakta, hipotesishipotesis yang pasti berdasarkan fakta serta kesimpulan pasti secara logis.

Berbeda dengan pengalaman mistik yang sangat menekankan definisi ulang atau interpretasi, apalagi karakternya yang tak bisa diungkapkan hampir pasti menambah derita pengalaman mistik dihadapan superioritas rasionalisme. Kesan-kesan kabur dari sesuatu yang tidak bisa didefinisikan tidak punya tempat dalam sistem yang rasionalistik ini. ${ }^{9} \quad$ Akan tetapi, sekuat apapun pengaruhnya, rasionalisme tidak mampu membahas pengalaman mistik dengan utuh dan holistik. Bahkan superiorioritasnya pun tidak mampu membungkam daya tarik pengalaman mistik.

9 William James dalam Gunawan Admiranto (Penerj), Perjumpaan Dengan Tuhan, Bandung, Mizan, 2004, Hal. 144 
Rasionalisme boleh berbangga selalu mengandalkan kejelasan dan unsur logis, tetapi pengalaman mistik tetaplah pengalaman mistik, dengan keyakinan dan dampak yang serba unik. Maka keyakinan yang tertanam dalam pribadi yang mengalami pengalaman mistik tak akan mudah dibantah. Atau dalam bahasanya James "jika anda memiliki intuisi, intuisi ini datang dari level sifat dasar anda yang lebih dalam dari pada level kefasihan kata-kata yang ditempati rasionalisme. Seluruh kehidupan bawah sadar anda, dorongan-dorongan hati anda, iman anda, kebutuhan anda untuk mendapatkan pengetahuan akan masa depan, sudah mempersiapkan premis-premis yang kemudian dirasakan hasilnya oleh kesadaran anda." Lantas apa yang harus menjadi kontribusi rasionalisme, selain kritik dan bantahan? Bagaimana rasionalisme bekerja demi terciptanya suatu pemahaman yang pasti tentang pengalaman mistik? Caranya rasionalisme harus membantu membangun keyakinan pada pribadi yang mengalami pengalaman mistik. Dalam artian rasio harus mendekatkan individu pada suatu keyakinan bahwa pengalaman yang ia alami tidak semata-mata tidak terungkapkan, tetapi bisa mengubah. Rasio bisa membawa seseorang pada kedalaman kebenaran (insight) yakni bahwa pengalaman ini merupakan peristiwa pencerahan dan pewahyuan yang penuh dengan makna dan arti (James).

\section{Pengalaman Mistik Dan Neurosis}

Ketika psike seseorang terganggu, terutama karena beban dari rasa frustrasi, cemas, takut yang berlebihan, ia akan mengalami sebuah ketidakseimbangan mental atau dalam bahasanya James disebut sebagai neurosis. Dalam pemaparan James, neurosis menjadi opini yang menarik terutama dalam pemahaman tentang pengalaman mistik. Sebagai seorang psikolog tentu tidak lupa James mengulas pengalaman mistik dari sudut pandang psikologis.

Suatu hal yang unik untuk ditelaah bahwa pengalaman perjumpaan dengan realitas transenden memang sulit untuk dijelaskan secara masuk akal yang oleh psikologi dicap sebagai unsur ketidakdewasaan mental. Dalam hal ini mereka yang mengalami pengalaman mistik diberi label sebagai orang yang menderita neurosis. Neurosis pada dasarnya adalah istilah yang berkaitan dengan psikologi dan berdekatan dengan bidang medis karena berhubungan dengan mental seseorang. Pengalaman mistik yang kadang dibanggakan, seringkali ditolak mentah-mentah oleh materialisme medis karena dianggap tidak lebih dari sebuah neurosis yakni gangguan jasmaniah sebagai akibat dari faktor-faktor 
mental atau gangguan fungsi jaringan-jaringan syaraf seperti hambatan instink karena emosi, keadaan cemas yang kronis dan sejenisnya yang menyangkut pengaruh faktor-faktor kejiwaan yang tidak normal. ${ }^{10}$ Kritik dan pendiskreditan terhadap pengalaman mistik menjadi hal yang biasa dalam dunia medis. Ini terlihat melalui penjelasan-penjelasan oleh James sendiri.

Materialisme medis menyimpulkan peristiwa penampakan yang dialami Paulus dalam perjalanannya ke Damaskus sebagai akibat dari luka di korteks otak (occipital cortex) yang mengeluarkan cairan. Dan ini hanya sekedar penderita epilepsi. Materialisme medis merendahkan derajat seorang Santa Teresa sebagai sekadar seorang penderita histeria, yang mengalami gangguan emosional ekstrim, mencakup gangguan fungsi psikis, sensoris, motoris dan syaraf, yang disebabkan oleh usaha represi terhadap konflik-konflik di dalam ketidaksadaran. Bagi seorang biarawati yang histeris, yang merindukan kehidupan normal, sosok Kristus hanyalah suatu pengganti imajiner bagi objek kasih sayang yang lebih membumi. ${ }^{11}$

Maka boleh dikatakan bahwa cara kerja materialisme medis dalam meneliti pengalaman mistik, ujung-ujungnya sama dengan cara kerja rasionalisme, menolak hal-hal mistik yang tidak sanggup dipahami secara akal sehat. Sama juga dengan sekularisme yang menolak hal yang bersifat metafisik. Sedikit penjelasan ini memperlihatkan betapa superiornya bidang psikologi terutama materialisme medis yang mencap orang-orang yang mengalami pengalaman mistik sebagai penderita neurosis. Akhirnya, seolah-olah pengalaman keagamaan ini begitu mudahnya dipatahkan kebenarannya oleh psikologi.

\section{Pengalaman Mistik Dan Halusinasi}

Halusinasi adalah suatu pengalaman yang mempunyai sifat presepsi, akan tetapi serupa stimulasi indera yang relevan atau yang memadai. ${ }^{12}$ Contoh dari fenomena ini adalah seseorang mengalamigangguan penglihatan dan ia merasa melihat suatu objek, namun indera penglihatan orang lain tidak dapat menangkap objek yang sama.

10 Drs. Sudarsono, S.H, Kamus Filsafat dan Psikologi, Rineka Cipta, Jakarta, 1993, Hal.168

${ }^{11}$ Op. Cit, William James dalam Gunawan Admiranto (Penerj), Hal. 71

12 James Drever, Kamus Psikologi, Bin Aksara, Jakarta, 1986, Hal.189 
Pengalaman penglihatan Santo Ignasius Loyola ketika ia berada di Manresa, yang pada akhirnya, pengalaman itu turut andil dalam titik balik hidupnya (pertobatan) maka, bolehkah dikatakan bahwa halusinasi visual ala Santo Ignasius Loyola merupakan pengalaman mistik?

Seperti yang dikatakan James dalam The Varieties of Religious Experience, bukti-bukti paling menarik sehubungan dengan rasa tentang realitas yang tidak terbedakan seperti ini bisa ditemukan dalam pengalaman halusinasi atau kata lain, pengalaman non-rasional yang dialami sebagai suatu yang nyata, sangat kuat sehingga hampir tampak seperti halusinasi.

Klarifikasi dua pernyataan di atas memberi kesimpulan bahwa sebetulnya pengalaman mistik dan halusinasi hampir mirip walaupun tidak persis sama. Benar bahwa pengalaman mistik itu terjadi seperti sebuah halusinasi, menyadari adanya "kehadiran asing", bersifat subjektif dan berlangsung singkat. Halusinasi itu bisa saja terjadi dan disebabkan oleh indikator-indikator yang sudah tertanam dalam kesadaran seseorang. Misalnya seseorang sudah mendapat cerita-cerita, dongeng atau dunia pendidikan yang menceritakan wujud makhluk halus terterntu yang disertai dengan deskripsi dan visualisasi dalam gambar atau lukisan. Visualisasi imajiner tersebut lambat laun terserap dalam kesadaran seseorang. Pada saat seseorang berada pada suatu peristiwa dan baru merasakan kekutan gaib, otomatis rekaman kesadarannya itu tervisualisasi secara imajiner. Sehingga ia bisa saja, seolah melihat suatu yang tampak nyata.

Hampir mirip dengan halusinasi, mengalami kehadiran asing yang "tampak nyata" namun dalam pengalaman mistik justru terjadi seadanya. Dalam arti terjadi tanpa atau karena ada rekaman tertentu dalam alam kesadaran. Keduanya (pengalaman mistik dan halusinasi) memang terjadi secara singkat, bersifat subjektif, bisa dialami oleh panca indera namun yang menjadi pembeda antara keduanya, boleh dikatakan, adalah proses terjadinya dan perkembangannya. Santo Agustinus, sebelum pengalaman mistik auditifnya, tidak pernah terekam dalam kesadarannya bahwa suatu saat akan ada suara gaib seorang anak kecil ${ }^{13}$. Atau Santo Paulus, tidak pernah didoktrinasi

13 Lihat Philip Burton, The Life of Saint Augustine, Dublin, 1897. St. Agustinus mengalami seluruh hidupnya sebagai pengalaman mistik. Diawali dengan suara anak kecil yang berseru tolle lege, tolle lege (ambil dan baca) di 
bahwa akan ada suara dan sosok "aneh" yang akan ia temui dalam perjalanan hidup dan pertobatannya. Bagaimanapun tetap ada perbedaan antara halusinasi dan pengalaman mistik. James sendiri mengatakan bahwa, sering terjadi sebuah halusinasi berkembang dengan tidak sempurna. Sedangkan pengalaman mistik (pengalaman religius) selalu berkembang ke arah yang positif yakni membawa seseorang pada keyakinan, metanoia dan kebahagiaan sehingga pribadi tersebut menjadi individu yang tidak hanya mampu mengembangkan diri sendiri tetapi juga menjadi pribadi yang mampu "melihat" realitas sekitar hidupnya.

\section{Pentingnya Pengalaman Mistik Dalam Hidup}

Secara Personal

Kualitas perasaan dan suasana batin seseorang selalu bermacammacam, sangat bervariasi tergantung bagaimana individu bersangkutan menanggapi pengalaman mistik yang ia terima atau alami. Bayangbayang kegelisahan, ketidaknyamanan, bahkan "kurang yakin" selalu menghantui. Bukan tidak mungkin, rasa takut, cemas serta menyalahkan diri sendiri selalu ada. Berbagai macam aspek perasaan itu telah menjadi integritas yang tidak mudah dipisahkan begitu saja. Ketika keyakinan individu atas pengalaman mistik yang ia terima, sungguh-sungguh hidup dalam dirinya, sudah tentu akan ada sebuah metanoia hidup. Kelanjutan dari metanoia itu adalah sebuah antusiasme hidup yang tidak terperikan. Antusiasme inilah yang memberi wajah baru dalam kesehariannya. Memperhatikan kehidupan para santo-santa, akan sangat berbeda jauh dengan orang lain yang tidak pernah mengalaminya. Berbeda ritme hidup yang dijalani pasti sangatlah kontras. Gairah dan semangat hidup, sekedar perbandingan, sangat jauh berbeda antara pribadi yang mendapat pengalaman mistik dengan pribadi yang tidak mendapat pengalaman ini.

Realitas kehidupan telah membuktikan bahwa mereka yang "secara beruntung" mendapat pengalaman bertemu dengan realitas asing biasanya sangat bergairah dalam menjalani hidup. Semangat dan

sebuah taman, saat kesedihan menyelimuti dirinya. Ketika itu juga ia berusaha menemukan pemilik suara itu tetapi tak sanggup ia jumpai. Lalu ia yakin kalau suara itu adalah a divine admonition to open the book and read the first page I should light on. Agustinus berubah menjadi pribadi yang sama sekali baru. Setelah sekian lama bergulat dengan kemewahan dunia, ia akhirnya sadar. 
antusiasme tinggi untuk menikmati setiap kesempatan, waktu, ritme hidup menjadi "wajah" mereka. Kepada dunia mereka bisa diperkenalkan sebagai santo-santa (tradisi Kristiani). Metanoia sebagai hasil refleksi atas keyakinan akan pengalaman mistik memberi dampak berbeda dalam hidup seseorang. Metanoia hidup Paulus menjadi titik balik kebiasaan hidupnya, berani berkoar-koar, mendobrak iman lama orang-orang yang hidup disekitarnya. Ia menjadi pembaharu. Ia seorang penyemangat hidup iman umat di zamannya, sekaligus berubah menjadi pribadi yang sarat akan antusiasme dan penuh gairah.

Hal lain, pikiran dan kesadaran akan dibawa pada sebuah realitas hidup orang-orang yang nota bene dalam hidupnya, selalu bergumul dengan pengalaman mistik. Artinya ada bukti-bukti yang bisa memperjelas sejauh mana efek yang ditimbulkan oleh sebuah pengalaman mistik. Semangat dan gairah hidup menjadi tanggapan yang serius dan bebas seseorang atas keyakinannya pada realitas pengalaman mistik. Semangat dan gairah hidup itu mengubah suasana hidup seseorang. Gairah dan semangat itu membawa seseorang pada perjumpaan dengan tujuan dasar hidup manusia. Tujuan itu adalah kebahagiaan. Karena itu, perjumpaan pribadi dengan realitas lain dalam hidup akan selalu menjadi wacana pembeda dalam rutinitas manusia.

Manusia selalu bermimpi untuk mendapatkan sesuatu dari setiap perjumpaan entah dengan sesamanya maupun dengan segala sesuatu yang terdapat dalam alam ini. Harapan inilah yang akan menjadi motivasi bagi manusia untuk berjuang, menaruh sebuah harapan besar terhadap pengalaman perjumpaan dengan realitas lain, yang serba transenden.

James membuktikan, "kehadiran Roh Tuhan yang dekat, kata seorang penulis Jerman, dapat dialami dalam realitasnya-bahkan memang hanya bisa dialami. Penanda dari eksistensi dan kedekatan roh ini, yang secara tidak terbantahkan sangat jelas bagi orang yang mengalaminya, adalah perasaan kebahagiaan tiada tara sehubungan dengan kedekatan ini"14

Moojan Momen dalam The Phenomenon of Religions menegaskan bahwa pengalaman religius atau pengalaman mistik dalam ungkapan James, merupakan suatu pengalaman yang membawa damai, sukacita yang meluap-luap meskipun dalam kesempatan tertentu bercampur rasa takut dan gentar (seperti dikuasai oleh kekuatan "luar"). Dunia Kristiani

14 William James dalam Gunawan Admiranto (penerj), Op.Cit, Hal.151 
mengenal begitu banyak orang kudus. Mereka jelas-jelas mengatakan kepada dunia bahwa mereka bahagia dalam dunianya sekarang. Hal pertama yang mengubah hidup mereka adalah pengalaman hidup mistik mereka. Daya juang untuk mencapai kebahagiaan surga terwujud melalui usaha untuk bersatu dengan realitas transenden dalam berbagai cara seperti meditasi dan kontemplasi.

Dengan demikian karakteristik pengalaman mistik tidak hanya menjadi pembahasan dalam dunia intelektual tetapi dapat diolah menjadi kekayaan individu. Memang tidak dapat diingkari apa lagi terbukti dengan berbagai dampak positif yang terjadi dibalik sebuah pengalaman mistik bahwa pengalaman ini membawa aura positif. Kiranya ungkapan James dan Momen serta hidup mistikus dalam dunia Kristiani tidak memberi kekecewaaan keyakinan individu atas hadirnya realitas asing dalam hidup. Sehingga mereka diberi keyakinan untuk menanggapi dan berusaha menggapai kebahagiaan melalui pengalaman perjumpaan dengan realitas asing yang diwahyukan kepada mereka apapun bentuknya dan kapan pun waktunya.

\section{Kehidupan Sosial}

Kebisingan zaman membuat manusia semakin sibuk mencari identitas diri sekalipun hidup dalam sekat-sekat tatanan sosial tertentu. Bahkan dalam usaha untuk menemukan identitas itu manusia kerap terjerumus dalam padang dunia yang begitu tandus akan hal-hal ilahi. Hal-hal yang besifat ilahi seakan hilang ditelan modernitas. Sebab yang dicari manusia saat ini adalah spiritualitas yang mengagungkan diri tanpa melihat campur tangan ilahi dalam dunia yang semakin hari semakin maju ini. Atau jangan-jangan Allah telah mati seperti yang dipikirkan Nietszche, karena sudah "dibunuh" oleh individu-individu modern.

Pernyataan mendasar Nietszche tentang ketidakhadiran Allah dalam dunia adalah opini yang sangat erat kaitannya dengan moralitas individu-individu modern. Karena gagasan tentang Allah sebagai supreme value yang tertuang dalam prinsip-prinsip moral diabaikan oleh manusia. Kebaikan yang seharusnya menjadi fondasi relasi tiap individu berubah menjadi tindak kejahatan untuk saling menghancurkan. Kebenaran yang seharusnya dibela justru menjadi angin-anginan saat orang melegalkan segala cara untuk meraup keuntungan dari sesamanya. Ini persis terjadi sebagaimana ada dalam dunia kapitalisme. Adanya kelas-kelas, majikan dan buruh adalah ciri dunia kapitalisme. Jika ditelaah lebih jauh dan dibenturkan dengan 
pendapat Nietszche (Allah telah mati) maka sangat jelas bahwa dunia kapitalisme telah kehilangan suasana ilahinya karena "dibunuh" oleh pribadi-pribadi yang serakah, yang hanya mengedepankan ambisi pribadi tanpa peduli realitas sosialnya.

Usaha untuk mendamaikan realitas sosial dan pengalaman mistik hampir pasti mengarah kepada suatu pertanyaan: mungkinkah? Memang benar bahwa pengalaman mistik dan realitas sosial adalah dua wacana yang saling bertolak belakang. Pengalaman mistik selalu berurusan dengan pengalaman akan kehadiran realitas ilahi sedangkan realitas sosial adalah dunia relasi atau hubungan antara individuindividu dalam hidup bermasyarakat. Maka hal yang bisa membantu untuk mendamaikan "realitas sosial" dan "pengalaman mistik" adalah melalui penghayatan religius.

Penghayatan religius termasuk salah satu penghayatan manusiawi berhadapan dengan kenyataan ilahi yang sulit diterjemahkan dalam bahasa manusia. Refleksi atas penghayatan religius manusia ini akan memperdalam pemahaman kita tentang diri manusia. Dalam refleksi atas penghayatan religius tersebut manusia menemukan dirinya terarah kepada Tuhan. Gabriel Marcel mengatakan I become conscious of the orientation of my personality towards the absolute Thou, God. (Aku menjadi sadar akan keterarahan diriku kepada sesuatu yang absolut, yaitu Allah). Dalam hal ini Tuhan ditemukan sebagai sesuatu yang the ground of all beings (dasar dari semua yang ada). ${ }^{15}$

Maka, menurut Caputo, semua orang beriman harus mewaspadai segala sikap ekstrim yang mengklaim bahwa agama atau kelompoknya telah dianugerahi hak istimewa untuk akses langsung kepada Tuhan dengan cara yang lebih istimewa atau bahwa kelompoknya telah mendapat panggilan khusus dari Tuhan. ${ }^{16}$ Sebab tindakan seperti ini akan membantu setiap orang beriman menjauhkan dirinya dari klaim-klaim kebenaran agama yang sepihak dan membuat mereka mampu menggali apa yang oleh Hick disebut family resemblances (kemiripan-kemiripan keluarga). Karena agama bukan hanya berkaitan dengan hal-hal teoritis melainkan hidup sebagaimana kita hayati. Agama menyangkut sikap mempercayai hidup, cara hidup dan yang paling penting untuk direnungkan adalah agama selalu menyangkut soal relasi atau

${ }^{15}$ Hipolitus K. Kewuel (editor), Mengolah Pluralitas Agama, Malang, Serva Minora, 2011, Hal.120

${ }^{16}$ Ibid, Hal.48 
perjumpaan dengan, yang oleh Rudolf Otto disebut "the wholly Other" atau "the Holly"17

\section{Penutup}

Demikian pengalaman mistik adalah suatu landasan dasar manusia berpijak dalam menjalin relasi personal dengan realitas transenden dan dengan dunia sosialnya. Pengalaman ini menjadi kaya akan makna ketika diimplementasikan dalam kehidupan. Bahkan tidak dipungkiri bahwa pengalaman ini menjadi inspirasi metanoia hidup seseorang. Di sinilah pengalaman mistik ini membantu manusia menemukan identitas atau jati diri yang sebenarnya, terutama dalam dunia yang sedang mengalami kemerosotan suasana religiusitasnya, akibat arus modernitas dan sekularitas yang pelan-pelan "mengeruk" pikiran tiap-tiap individu modern. Pengalaman mistik menjadi landasan tiap-tiap individu untuk melangkah lebih jauh ke dalam realitas dunia dan melihat dasar hidup yang sebenarnya.

Bahwa banyak hal yang mulai hilang sejak manusia menjadi pribadi modern. Bukan semata ia kehilangan kekunoan hidupnya tetapi terlebih ia kehilangan "kebutuhan batin" yang merupakan pusat kesadaran dirinya sebagai pribadi yang hadir dalam rutinitas zaman. Manusia seolah kehilangan fondasi hidupnya yakni relasi dengan realitas tertinggi yang menggagas hidupnya. Manusia mengalami kemerosotan eksistensinya sebagai makhluk religius. Semuanya hilang oleh sikap manusia sendiri. Manusia terlanjur mengapung di atas arus kemajuan zaman dan tidak mampu berenang melawan derasnya arus yang menghempasnya. Karena itu manusia menjadi pribadi yang hanya "ikut arus" tanpa mampu membedakan mana yang positif dan mana yang negatif. Semua hal di dunia, dalam zaman adalah baik baginya. Karena semuanya baik, ia kehilangan hal-hal yang paling mendasar dalam eksistensinya. Salah satunya kebutuhan spiritualitasnya.

Modernitas dan sekularitas zaman memberikan label baru pada manusia. Manusia menganut paham spiritualitas sekular. Karena itu "suasana religius" dalam dirinya pun berangsur-angsur hilang. Manusia mengalami kekerdilan jiwa sehingga tidak sanggup untuk melihat "sumber hidupnya" serta relasinya dengan orang lain. Mungkin juga karena tidak mau berlama-lama larut dalam kemerosotan eksistensinya, manusia menggagas opini lain sebagai pegangan hidupnya, agar ia

${ }^{17}$ Ibid, Hal.72 
kembali ke ranah spiritualitasnya yang semula. Pengalaman mistik akhirnya menjadi perhatian penting untuk meningatkan kembali relasi personal manusia dengan "Tuhannya" sekaligus, di sisi lain manusia diberikan warning tentang relasinya dengan sesama.

$$
===0000====
$$

\section{DAFTAR PUSTAKA}

James, William dalam Admiranto, Gunawan (Penerj), 2004. Perjumpaan Dengan Tuhan, Mizan, Bandung.

Burton, Philip, 1897. The Life of Saint Augustine, Dublin.

Kewuel, Hipolitus K (Ed), 2011. Mengolah Pluralitas Agama, Serva Minora, Malang.

King, Richard, 2001. Agama, Orientalisme dan Poskolonialisme, Qalam, Yogyakarta.

Parsons, William B, 1999. The Enigma of the Oceanic Feeling, Oxford University Press, New York.

Underhill, Evelyn, 1915. Practical Mysticism, Ebook Directory, USA.

Zaehner, R.C, 1961. Mysticism Sacred and Profan, Oxford University Press, London.

Drever, James, 1986. Kamus Psikologi, Bin Aksara, Jakarta.

Drs. Sudarsono, S.H, 1993. Kamus Filsafat dan Psikologi, Rineka Cipta, Jakarta.

Heuken SJ, A., 2005. Ensiklopedia Gereja, Yayasan Cipta Loka Caraka, Jakarta.

https:/ /afidburhanuddin.wordpress.com/2012/11/05/william-jamesbiografi-dan-pemikiran/.

https://id.wikipedia.org/wiki/William_James. 